\title{
IL17C wt Allele
}

National Cancer Institute

\section{Source}

National Cancer Institute. IL17C wt Allele. NCI Thesaurus. Code C50924.

Human IL17C wild-type allele is located within 16q24 and is approximately $2 \mathrm{~kb}$ in length. This allele, which encodes interleukin-17C protein, is involved in regulating the release of TNF-alpha and IL-1 beta from monocytes in inflammatory immune responses. IL17C differs from IL17 in its pattern of expression, biologic activity, and lack of interaction with IL17 receptor. 